\title{
Antonio Argandoña
}




\title{
CAN CORPORATE SOCIAL RESPONSIBILITY HELP US UNDERSTAND THE CREDIT CRISIS?
}

\author{
Antonio Argandoña ${ }^{1}$
}

\begin{abstract}
The financial crisis that started in the United States in 2007 and which has spread throughout the world has many causes, one of which is the abundance of unethical behaviors on the part of many of those who made the financial decisions - such as regulators, supervisors, managers or employees - and also on the part of a not insignificant number of their clients. In this paper, we will seek to shed light on the crisis's ethical content and show how the generalized practice of corporate social responsibility within financial institutions could have helped reduce the magnitude of the crisis, perhaps not systemically but definitely in some of the organizations that have been most affected by the crisis. However, to do so, it would have been necessary to apply a particular concept of social responsibility; a responsibility with an ethical basis - or, more specifically, a voluntarily-assumed code of ethics that was capable of giving rise to selfgenerated duties among financial decision-makers.
\end{abstract}

Classification JEL: G12, G31, M21

Keywords: Crisis, ethics, finance, corporate social responsibility, financial system.

\footnotetext{
${ }^{1}$ Professor of Economics, "la Caixa" Chair of Corporate Social Responsibility and Corporate Governance
} 


\section{CAN CORPORATE SOCIAL RESPONSIBILITY HELP US UNDERSTAND THE CREDIT CRISIS?}

\section{Introduction}

Since mid-2007, the world economy has been immersed in a far-reaching financial crisis that has culminated in a deep recession. ${ }^{1}$ As with any complex economic phenomenon, the crisis has not only economic causes but also psychological, social, political and ethical causes. Obviously, every expert will view the problem through the filter of his or her particular specialty and tend to play down the other explanations. However, these should not be seen as alternatives but rather as explanations that complement each other. Accordingly, this paper proposes a reflection on the crisis's ethical causes, seeking to answer three questions: 1) Is this not just an economic, political, psychological or social crisis but also an ethical crisis? 2) What does the ethical interpretation add to the other explanations of the crisis? and 3) Would it have been possible to avert the crisis if the various players, particularly in the financial institutions, had acted ethically?

This last question is not asked in terms of ethics but of Corporate Social Responsibility (CSR). The reason for this is eminently pragmatic: in the financial world, the concept of CSR is much more widely accepted than ethics, probably because it is less demanding and, therefore, less controversial. However, this makes it more difficult to answer our questions: according to some concepts of CSR, more responsible conduct could have averted the crisis or, at least, made it less likely to happen and moderated its impact, but not according to other concepts and contents of CSR. So, in the end, we have no choice but to discuss what CSR is, in order to ascertain which concepts of CSR could have provided guidelines for understanding the crisis, its causes, and how to avoid it in the future.

\footnotetext{
${ }^{1}$ Here, we make a distinction between financial crisis (a situation characterized by severe disruptions in the value of financial institutions' assets, their access to funding or their clients' trust, to the point of endangering the financial system's sustainability) and recession (a situation marked by the deterioration of variables such as output, consumption, investment, employment and expectations). A financial crisis usually becomes an economic recession, but the latter may happen without the former. Cf. Abberger and Nierhaus (2008), Claessens et al. (2008), Mendoza and Terrones (2008).
} 
In a rather roundabout fashion, this paper addresses this issue in three parts. In the first part, we ask what CRS is: not to give a definition but to understand what these responsibilities accepted by the company consist of. We then discuss what the word responsibility means, what is meant when it is said that CSR is a moral responsibility, what concept of ethics is applicable to this idea of CSR, why should a company be responsible, what content does this CSR have and what are the financial institutions' social responsibilities. The second part tries to answer the first two questions: the morally incorrect or doubtful conducts that have led to the present situation are analyzed in order to answer the question of whether this crisis is an ethical crisis, and an attempt is made to elucidate what the ethical explanation can add to those explanations that have already been made from the economic (and social, psychological, political, etc.) viewpoint. Lastly, the third part tries to answer the question of whether CSR could have averted or, at least, attenuated the crisis's effects, stressing particularly the loss of trust that has taken place. The paper then closes with the conclusions.

Here, we have addressed the problem from the viewpoint of a financial firm, not of the system as a whole. In other words, we are not concerned with the possibilities and limitations of regulation and control as a whole (Kane, 2009), nor with the policies that could have averted the crisis or which may help overcome the crisis, but in what way the specific conduct of the financial institutions' directors, managers, analysts and employees have contributed to the present situation.

\section{What is Corporate Social Responsibility?}

The abundant literature on Corporate Social Responsibility has not helped in establishing a consensus on what we are talking about. However, this should come as no surprise to us; the fault does not lie with CSR. For many people, CSR is normative, that is, it is concerned with what the company must do, what is expected from it, and its obligations and duties, ${ }^{2}$ although these actions' compulsoriness is not founded on law but rather on some form of voluntary undertaking or ethical requirement. ${ }^{3}$ However, we will not be able to come to an agreement on these duties' contents if, first of all, we cannot agree on their whys and wherefores: what is expected from the company and what its goals are - in short, what the firm is. I doubt very much whether we will come to a sufficiently generalized consensus on the matter because, in actual fact, the disagreements go beyond CSR and the firm and refer to how we view the society we live in and the nature of the agents who are part of it.

However, let us start by asking what the R, responsibility, in Corporate Social Responsibility means.

\footnotetext{
2 Donaldson and Preston (1995) identify three approaches to CSR: descriptive (explaining how managers take account of their social responsibilities); instrumental (CSR is a means to a different end; namely, shareholder value maximization); and normative (explaining how a company that wishes to be socially responsible must behave).

3 The voluntary nature of companies' commitment to CSR is underscored in many definitions. Cf., for example, European Commission (2001), International Chamber of Commerce (2002), World Business Council for Sustainable Development (2000).
} 


\section{What is Responsibility?}

\section{Ethical responsibility}

What do we mean when we say that a person or an organization is "responsible" for something - an action or omission, and its effects or consequences? (Eshleman, 2004; Hart, 1968; Williams, 2006). ${ }^{4}$ Responsibility is a moral category: "to say that a person is responsible (...) for a given action is only to say that it is appropriate to take it as a basis of moral appraisal of that person" (Scanlon, 1998, p. 248). As such, it is part of every human action.

The moral dimension of responsibility can be approached from five different viewpoints: 1) as an attribute of the individual's actions; 2) as the accountability for these actions; 3) as a duty or obligation; 4) as the individual's attitude, and 5) in the long run, as consistency in life. Of these, the two that interest us most for our purposes here are the first and the third.

1) Responsibility, strictly speaking, appears when an action (or omission) and its effects are attributed to a person, or accepted by him, not only as the cause of the action, but as a "moral agent". It is retrospective: an agent acted (or failed to act) in the past, and the resulting moral responsibility for the action and its consequences are attributed to him. ${ }^{5}$

2) Responsibility as the attribution of moral responsibility implies that the agent is accountable for his action to himself and to others (Oshana, 1997). It is social, i.e., owed to another person or community, and so subject to the normative standards required of interpersonal behavior; it is subject to external evaluation and sanction, and it implies duties of disclosure and transparency.

3) Moral responsibility may also be understood as a duty or obligation: a prospective responsibility (Jonas, 1984). Responsibility as an obligation presupposes a willingness to account for this responsibility and the means employed, and to shoulder the consequences, including compensation for any damage that may be caused.

4) The agent's response to prospective responsibility leads to responsibility as an attitude: the agent's willingness (responsiveness) to respond to others. It is founded on a person's ability to make genuine moral decisions for herself, so that she can be relied upon to meet her obligations and accept the consequences of her acts.

5) Responsibility lived as something continuous and enduring implies consistency in life: the individual is not only responsible for his actions but also, above all, for creating the conditions - virtues - that will enable him to live at all times in accordance with that responsibility: in other words, it determines, to some extent, his entire biography (Argandoña, 2008e).

\footnotetext{
${ }^{4}$ For a more detailed analysis of the arguments that follow, see Argandoña (2008a).

${ }^{5}$ For this attribution of moral responsibility to occur, two conditions have to be met: the action must be voluntary, that is, it must meet certain conditions of awareness, consent and freedom, and there must be a (legal, social or ethical) norm to which action must adhere and against which it may be judged.
} 


\section{Social responsibility}

CSR is frequently understood as a response to the demands or expectations of society (Carroll, 1979). And, certainly, society expects or demands certain behaviors from all those who belong to it. But the question is whether there is a responsibility (duty) that originates in these social expectations, but not in ethical (or legal) duties.

We conclude that there is no such responsibility (duty) (Argandoña, 2008c): whatever society's demands and expectations may be as regards companies, if they do not create true moral or legal obligations then they will instead be accepted for reasons of opportuneness or expediency (as is also the case for many social norms, such as the rules of etiquette), because their benefits (and not necessarily economic benefits) are greater than their costs, or to avoid rejection or gain other people's acceptance. ${ }^{6}$ In any case, the social norms arising from these demands or expectations may help define the content of an ethical norm (for example, to define what society understands by unfair discrimination).

So what does the adjective 'social' add to companies' responsibility? The accountability dimension of ethical responsibility. The socially responsible company accepts its duty towards society, with all that this entails as regards explicit recognition of its duties, public disclosure of these duties, accountability, and transparency in its management of CSR.

\section{Responsibility for the common good}

Since Jonas (1984), it has become commonplace to consider that we are all responsible to some degree for everyone's actions, insofar as we all take part in one way or another in a network of relationships which, at the same time as it diffuses our responsibilities, also serves to accentuate them, precisely because it becomes more difficult to attribute this responsibility to a particular person or group. This concept of responsibility is prospective and positive, and it is also social, insofar as it "ascribes to a particular person or persons, or, more likely, institution(s), the responsibility to actively prevent future harm to humans and nature, or realize desirable future conditions by taking the necessary measures in the present" (de Villiers, 2002, p. 17).

However, it does not seem that this responsibility is different from moral responsibility as a duty mentioned earlier; it simply extends to society as a whole the responsibility arising from a direct relationship with other people. Or, to put it another way, it extends it to the common good as a good shared by everyone, made possible through the cooperation of everyone and aimed at developing everyone's potential within society (Argandoña, 2009a). ${ }^{7}$

\footnotetext{
${ }^{6}$ Another reason is that society's demands may be unjust or immoral, because of the nature of what is demanded, or because the demands place an unfair burden on companies, or because they tend to serve the interests of the powerful (Gössling and Jansen, 2006).

${ }^{7}$ In any case, the content of social responsibility understood as a responsibility for the common good is different from that of responsibility for the agent's personal actions. We are all responsible for global warming but in a different sense from the responsibility we have for heating our room. And the way we address this responsibility is also different, consisting, probably, not so much (or not only) of turning down the household heating as of changing the "rules of the game" concerning the production and use of energy in society (Beckmann and Pies, 2007).
} 
There is also a legal responsibility, founded on the law. Obviously, moral and legal responsibilities are connected but they share neither the same origin nor the same scope. Legal responsibility is based on criteria of social necessity or efficacy, not necessarily on moral criteria; that is why the law sometimes attributes responsibility for an action to an agent, even though objectively no moral responsibility can be attributed to him. Furthermore, the law does not encompass all moral obligations - nor should it, as to do so would be detrimental to freedom. There are also times when the legal norm requires people to act against the ethical norm. And the law tends to be reactive and cannot easily adapt to new circumstances and problems, whereas morality is (or should be) proactive and flexible.

Laws are often obeyed for expediency reasons (to avoid penalties) or cost-benefit reasons. However, above all else, abiding by (just) laws is a moral duty. The existence of controls and penalties does not mean that this is not voluntary: anyone who considers that abiding by business rules is a moral duty does so voluntarily (and she would do so even if the controls and fines did not exist) and, possibly, she takes her moral duty beyond the mere observance of the law.

\section{Corporate Social Responsibility as a Moral Responsibility}

The points we have briefly developed in the preceding paragraphs lead us to a series of conclusions about CSR which will be relevant for the purpose of our paper.

1) Every organization has numerous ethical responsibilities of a very varied nature: it is responsible for all its actions and omissions, its strategies and policies, how it influences the people who act in or around it, and how all the above affects the organization itself, those who participate in it or have dealings with it, and society as a whole.

2) CSR addresses the ethical responsibilities that the company accepts towards society or its stakeholders, because it is required by law, because they form part of its function or because the organization accepts them voluntarily.

3) CSR is an eminently ethical responsibility. Ethics does not specify the content of an organization's responsible management but it does give reasons for abiding by these responsibilities and also contributes to giving them a breadth that goes beyond the strictly managerial sphere.

4) As an ethical responsibility, CSR issues a moral judgment on the (past) actions of the person performing them, based on previously mentioned variables (awareness, consent and freedom), and on the existence of a norm which the moral agent must have interiorized.

5) The existence of a norm (legal, traditional, moral, social...) on which this responsibility is founded implies another dimension of CSR: it gives rise to certain duties or obligations on the part of the agent towards himself and others. These are not generic duties but are directly related to the agent's legal or social position and, therefore, with the social function he performs. ${ }^{8}$

\footnotetext{
${ }^{8}$ Therefore, although the Chairman, the CEO, the analysts or the accountants will have different responsibilities, they will all share a certain common responsibility because they are all members of the same organization.
} 
6) CSR's ethical dimension also implies the agent's accountability towards others, which in return requires an attitude of transparency and openness.

7) Ethical responsibility leads to an attitude of responsiveness on the part of the agent towards others in the performance of her functions. Logically, this attitude will induce the agent to focus her entire conduct towards consistency in her life, which we have explained as the creation of conditions which will enable her to live at all times in accordance with her responsibilities. This raises issues that will re-emerge in our analysis of the financial crisis, for example, with respect to the existence of perverse incentives, conflicts of interests or negative learning.

8) CSR's "social" dimension is not conditioned by social requirements or demands, although some of these expectations form part of companies' moral responsibilities.

9) Although CSR does not encompass everything that happens within and around organizations, it does include their participation in the common good: we all have a certain degree of responsibility towards the other stakeholders and towards society as a whole.

10) Although we have not mentioned this before, it is obvious that CSR is not confined to "good works", charity, social action or philanthropy. They may be part of CSR, but they are not to be identified with it.

11) Companies also have legal responsibilities which, insofar as they are also ethical responsibilities, will also be part of their CSR.

\section{What Ethics?}

If CSR is not a strictly legal obligation, it is not made mandatory by the controls and sanctions of law but by ethics. It is voluntary insofar as it is not adhered to out of any external coercion. However, it is not discretionary in the sense that companies can take it or leave it as they choose, but normative or prescriptive: the company "must" take its responsibilities into account as a moral obligation (an obligation of conscience), whether or not that obligation is backed by the force of law or social norms.

But that leads us to another question: what ethics are we talking about? Because there are many theories on ethics but not all of them are capable of autonomously generating selfenforceable norms, norms that do not depend on the existence of a law and the coercive power of the state, or "on social regulation and (...) to retributive and compensatory justice" (Watson, 1996, p. 243) ${ }^{9}$ exercised through a game of rewards and punishments.

"The enforceability of the [moral] norms depends (...) on the moral constitution of individuals; that is, of their internal motivational structure, much before any exogenous system of enforcement" (Zamagni, 2006, p. 9). However, this is not the appropriate place for developing this subject..$^{10}$ Suffice to say that the mechanism that allows this to happen is the moral virtues: they are the means of internalizing the effects that actions have on the agents' moral quality. Virtue ethics is thus able to explain the type of voluntary behavior that here is attributed to

\footnotetext{
${ }^{9}$ Quoted by Fischer (1999), p. 97.

${ }^{10}$ See Argandoña (2008b, d, e); my main source is Pérez López (1993).
} 
CSR, and it does so from within the action itself: the agent must be ethical and practice the moral virtues because that is the best way to achieve the goals of his actions, not just in an isolated decision, but over the course of a lifetime. ${ }^{11}$

\section{Why must a Company be Responsible?}

The consequence of all this is that a good company, an excellent company, exercises its ethical responsibilities - and if it does not, it will not be a good company, even if it earns high profits and has an enviable stock market performance and a highly valued reputation (Argandoña, 2008f). It is not a technically and financially "correct" company to which certain social and ethical "values" have been "added" or which has instruments such as a code of ethics or a social responsibility manager, or which exceeds the requirements stipulated by a certifiable standard on ethical, social or environmental aspects.

A socially responsible company has "another" way of viewing problems, as it will always be aware of the consequences of its decisions on all of the people concerned: the managers themselves, employees, customers and suppliers, the local community, society as a whole and even future generations (the environmental dimension). It will "see" things - consequences, problems - that other companies will not see, important things - perhaps not for short-term return but very important for the consistency of its policies and actions, stakeholder engagement or for generating trust between stakeholders and with the organization (Argandoña, 2008e). And a different range of opportunities will open up before it; it will consider that some "solutions" are not open to it because they are immoral while, on the other hand, it will perceive other opportunities, precisely because of the climate of trust created and the abilities it will have developed in its human team and with other stakeholders.

This is just a brief outline of what makes a socially responsible company "different". However, the consequences that arise from this are many and highly significant. For example, if ethics is taken into account in corporate strategy-making from the very beginning, a responsible company cannot have the same strategy as another company that is not responsible: other significant facts will be identified, they will be rated differently, the diagnoses will also be different, it will consider different alternatives, people will learn differently... its history will be written differently and the future will also be seen differently. And those who are not ethically responsible will not realize these differences. As a result, they will in all likelihood make wrong decisions: perhaps not wrong for short-term return but they will be wrong for the long-term consistency of their actions.

In a way, what the responsible manager does is "change" the questions - something that it is not easy to do when that change is not wished for (if the previous strategy has been successful, why change it?) or cannot be implemented (when one is trapped in certain customs and routines whose consequences are not fully appreciated) or it is not known how to implement it (because the underlying causes are not known) or because, even though the change is wished for, the means for making it are not available (because the decision-makers lack the necessary virtues).

\footnotetext{
11 "The key to the ethic of virtues is in its capacity to resolve the opposition between self-interest and interest for others, between egoism and altruism, by moving beyond it (...) The virtuous life is the best not only for others - like the various economic theories of altruism would have it - but also for us" (Zamagni, 2006, p. 9).
} 
Furthermore, "changing" the questions, deciding to behave ethically, means making one's life more complicated. It becomes necessary to consider the effects that one's decisions have on those who are affected by them, starting with oneself; to pay attention to everyone's needs; to ask what is the best decision in each individual case and abandon the convenience and security of the "well-trodden paths", "it's what everyone does", the ready-made recipes: in short, it requires asking in each case what we are "really" looking for and how honest our intentions are. Of course, this is not easy, particularly when it confronts us with the need for profound changes.

This leads us to one important conclusion: many wrong decisions are not so much immoral decisions as bad decisions - or rather, the fact that they are immoral shows that they are bad. And many corrupt or dishonest managers are, above all, incompetent managers.

\section{The Content of Corporate Social Responsibility}

What is a firm responsible for? For our purposes, it may be useful to distinguish between their internal responsibilities (towards its members or internal stakeholders: owners, managers and employees) and external responsibilities (towards its clients, suppliers and society in general).

1) The responsibilities towards internal stakeholders will depend on the motivations that led them to join the company; that is, the satisfaction of certain needs (defined in a very broad sense: compensation, knowledge, skill development, acquisition of virtues, human relations...). And not just satisfying any need, but precisely those that led them to join the organization (Pérez López, 1993; Argandoña, 2008d, e), and satisfying them efficiently, as befits a business organization (value creation).

2) The people who work in the company do so because it is the only - or most efficient way to achieve a joint result that none of them could achieve on their own or only inefficiently. This is its social function, which defines the company's external responsibilities: what needs of what individuals outside of the organization (clients, suppliers, local community, etc.) does it try to satisfy through the production of goods and services (including, if applicable, other effects that are not sought directly, such as pollution, traffic jams or knowledge development). This social function is specific to each type of company and, therefore, will be different for a travel agency, a hedge fund or a hospital. And its definition will not depend on ethics but will be determined, first of all, by technical and economic criteria, as we will see further on.

\section{The External Social Responsibilities of Financial Institutions}

What is the social function of a financial institution? To provide brokerage services that facilitate the flow of savings towards investment (Argandoña, 1995a; Haig and Hazleton, 2004; Hogan and Sharpe, 1997; Merton and Bodie, 1995; Prior and Argandoña, 2009a; Scholtens, 2006, 2008). A financial intermediary issues liabilities that it places among savers, either directly or through another intermediary, and buys assets (provides credit) from those who plan to make an investment. This social function will be further defined for each institution. For example, a commercial bank offers savers a broad range of assets with varying features as regards maturity, liquidity, return, etc., so that they may place their wealth in the manner that suits them best, including access to an efficient payment system with low transaction cost. Accordingly, this function contributes to the wellbeing of families and businesses by enabling them to manage their wealth with acceptable liquidity, return and risk levels. On the other side 
of the financial brokerage function, the bank makes available the resources received from savers to those who wish to make investments (credits, loans, securities), with a broad range of features as regards cost, term, collateral, etc.

Thus, we can define three levels of social function - of the financial system as a whole, of each type of institution and of a specific institution - which in turn define three levels of social responsibility.

1) The first, the most abstract, is accepted by the system as a whole and, in a free (albeit regulated) market economy, it is not attributed to anyone in particular: it gives rise to a responsibility that is shared by all institutions, each one in their respective sphere, and by the regulators and supervisors, each one within their respective function.

2) The second level defines the social function of each type of institution. A commercial bank, for example, cannot ignore the restrictions imposed by law and regulation (on such varied aspects as the nature and volume of its capital, the accounting criteria it must follow or the geographical area in which it operates) or the social function of commercial banking: the maturity transformation of assets and liabilities (banks "borrow short and lend long"), the provision of liquidity, the management of debtors' risk, etc. Some of these functions are also performed by other organizations, but all of them are included, to a greater or less extent, among those of the commercial banks, perhaps by law but, above all, because banks are better placed than their depositing customers to carry out these functions.

3) After accepting these two levels of external social responsibility, there remains a space within which each institution can define which services it will render and to whom (what type of deposits it will promote, which loan customers it will seek most aggressively, etc.). ${ }^{12}$

Note that these responsibilities have a technical-financial content, both because of their goals (they fulfill what is expected from them as financial institutions) and because of the resources used (all of them of a technical-financial nature). However, they are also moral (they are part of a good manager's ethical duties) and social responsibilities (because the institutions themselves take on a commitment to society to develop all of these functions, including the duties of transparency, information, etc.) (Argandoña, 1995b; Boatright, 1999; Carrasco, 2006; Cowton, 2002; Cowton and Thompson, 1999; Lynch, 1991, 1994). And it is this combination of technical knowledge and expertise on one hand, and moral and social attitudes, on the other hand, that creates the trust on which any lasting relationship between financial institutions, their clients and the society in which they operate must be based.

In short, the primary external social responsibility of a financial institution is to perform its social function, which will be specified in the above-mentioned responsibilities. To this must be added, as is logical, the responsibilities that arise from its nature as a business (profitability, self-continuity, social efficiency) and as an organization (care for the interests and needs of its

\footnotetext{
${ }^{12}$ All three levels of social responsibility should also take into account the circumstances of the environment in which they operate: for example, in a developing economy, it cannot remain aloof from factors such as the financial exclusion of a large proportion of the population, deficient governance, the need to support productive activities that improve citizens' standard of living, etc. (Argandoña et al. 2009b).
} 
internal stakeholders), and from any social, philanthropic and patronage activities it wishes to engage in.

\section{Is the Financial Crisis an Ethical Problem ${ }^{13}$}

In this section, we assume that the reader is aware of the nature and causes of the financial crisis, both those that are indirectly related (the years of financial stability, high, sustained growth, abundant liquidity, low interest rates, etc., and the financial innovations that have emerged in recent years: significant growth of subprime mortgages, securitization and development of financial derivatives, blurring of boundaries between organizations, complexity of the financial system, etc.) and those that are directly related (rising interest rates in the United States after 2004, end of the real estate boom, increasing default rates on subprime mortgages, etc.), and their evolution from early 2007. This assumption will enable us to focus on the ethical elements of the crisis. ${ }^{14}$

\section{Ethical Failings at the Heart of the Financial Crisis}

Ethics-based explanations of the 2007 financial crisis have appeared frequently in the media and have referred to bankers' greed, the multiplication of fraudulent operations, the creation of perverse incentives and imprudent behaviors. ${ }^{15}$ Is this really an ethical crisis? To an extent, yes: all human conducts have technical-financial, social and moral dimensions, and the behaviors that led to this crisis are no exception. But is this explanation sufficient?

Greed

It is said that this crisis has been caused by greed, understood not as the simple pursuit of profit, but as the perversion of the legitimate right to financial gain. And this is true: but this thesis tries to explain too much. All of us or, at least, many of us are greedy and, as a race, we have been greedy for centuries. But this is something we already know: that is why we design and implement control mechanisms (laws, regulations and judges) not to prevent greed, ${ }^{16}$ but to prevent it from degenerating into fraud and corruption, at least to an alarming degree.

What has happened in recent years is, probably, that 1) conditions have been created (low interest rates, abundant liquidity, rapid growth in the price of assets, financial innovations...) that have allowed the financial gain obtained with such behaviors to be much greater; 2) society has also generated situations of "induced greed", encouraging and rewarding those who

\footnotetext{
${ }^{13}$ A shortened version of this section can be found in Argandoña (2009b).

14 There are many excellent analyses of the financial crisis that started in 2007; for example, Baily et al. (2008); Bordo (2008); Brunnermeier (2008); Diamond and Rajan (2009); Eichengreen (2008); Hellwig (2008); Kane (2008); Taylor (2009).

${ }^{15}$ It is common to denounce ethical failings after all periods of boom and financial crisis. Cf., for example, Bogle (2006), Kindleberger (1978).

${ }^{16}$ The law normally does not seek to directly change people's characters but rather their actions or, at least, the consequences of their actions.
} 
are successful in their greedy behaviors ${ }^{17}$ and making it more difficult to behave otherwise, and 3) some of the regulation and control mechanisms have failed.

If this diagnosis is correct then there is an underlying ethical problem, but where the failures have occurred has been, above all, in regulation and supervision: first, by allowing creation of certain conditions that subsequently enabled extraordinary opportunities for profit to appear and, second, by not preventing excessively risky conducts, legal or otherwise, and fraudulent behaviors.

But this does not mean that we are facing a purely technical problem, without any ethical content. Doubtless there are technical elements (how supervision and control mechanisms are designed and implemented) but there are also moral elements, because these mechanisms are not neutral and given but are designed and implemented by people and, therefore, they are also decisions with an ethical dimension. In recent years, we have seen situations that would come under this category: environmental changes (excessively low interest rates for too long, real estate bubbles, etc.) and institutional and regulatory changes (abolition of the Glass-Steagall Act, fostering of subprime mortgages by government-sponsored organizations such as Fannie Mae and Freddie Mac, resistance to regulating certain financial derivatives, etc.). I would not go so far as to say that these changes have always been caused by greed, but I would at least say that they have encouraged it or have not contained it sufficiently.

This argument can be looked at another way: in recent years, perverse incentives have been created, probably sustained on greed. ${ }^{18}$ It is these incentives that have disseminated and exacerbated immoral conducts and have even led to the suppression or mitigation of the mechanisms and institutions established to control their effects. ${ }^{19}$ Perhaps the most obvious perverse incentive is that which induced "key personnel in virtually all important financial institutions - including commercial and investment banks, hedge and private equity funds, insurance companies and mutual and pension funds - to take excessive risk" (Crotty and Epstein, 2008, p. 4), ${ }^{20}$ to the point that it has been said that the crisis was a catastrophic failure of financial risk management, at all levels, from governments, regulators and supervisors to many of the financial institutions and their clients.

\footnotetext{
${ }^{17}$ In other words, the greed we are talking about here has a significant social content: beyond personal tendencies, it has been motivated, encouraged and, sometimes, exacerbated by social attitudes and conducts. This raises an important question: how can an individual oppose a vice that is condoned by a large part of society?

${ }^{18}$ Here are some examples: 1) Mortgage brokers' compensation was based on the number of mortgages signed, not on their likely solvency. This fostered risk-taking in granting this type of loan and even giving false information on the application forms. 2) The banks that granted the mortgages quickly securitized them and took them off their balance sheets, which eliminated their incentive to strictly check their clients' credit rating and monitor repayment of the loans. 3) Some borrowers bought dwellings with the intention of defaulting shortly after and then buying another house at a higher price with a bigger mortgage. 4) The financial institutions often incurred moral risk problems, engaging in high-risk operations with the assurance of an explicit or implicit government guarantee on deposits and other liabilities. 5) The investment banks, which had been private partnerships, became public corporations, which reduced their liability for losses and encouraged higher risk strategies. 6) The increase in managers' compensation, often tied to stock options, led them to seek short-term results, often involving risky or even fraudulent operations. Cf. Kane (2008).

19 Due, among other reasons, to the regulated organizations' own lobbying, which raises further doubts as to the morality of their actions (Kane, 2008).

${ }^{20}$ Including the illusion that risk had been eliminated from institutions' portfolios, for example, through the use of Credit Default Swaps (CDSs).
} 
A particular case of perverse incentives would be the conflicts of interest (Argandoña, 2004) that have arisen, for example, in the rating companies, whose revenues depended to a large extent on the valuation they gave to the assets submitted by their clients. ${ }^{21}$

A highly popular variant of the greed argument attributes the crisis to the high salaries and bonuses paid to managers and financial analysts. However, it does not seem that this has been the cause but rather the effect: money goes to what is fashionable at the time and, in the last few years, what has been 'in' is real estate and financial assets. And wherever money goes, prices rise, generating rents that the various agents involved try to capture. Managers have a comparative advantage in knowing what these rents are, where they are generated and how to capture them, and the analysts and other experts have also shared in this rent capture because their technical contribution was necessary to create them.

In any case, high compensation does not go even remotely towards accounting for the huge losses suffered by the banks affected and the nature of the problems caused by the crisis. What high compensation (including the golden handshakes) has done is to generate perverse incentives and foster conducts aimed at maximizing managers' compensation rather than the financial institutions' profits, leading to account rigging in some cases. ${ }^{22}$ In any case, the design and implementation of these compensation schemes has also been an imprudent conduct and an example of poor governance, precisely because nobody foresaw these perverse incentives.

Has the crisis been caused by the cases of fraud, such as that of Bernard M. Madoff? The answer again is no. As we have already said, the temptation to carry out fraudulent activities always exists and it is the regulators' and judges' task to prevent them from happening, although it is probable that, in a climate of euphoria and opportunities to make extraordinary profits, the temptation to cheat will be greater, particularly if it coincides with a relaxation of controls. $^{23}$

More damaging may be the "legal fraud" consisting of "regulatory arbitration," by which operations are moved to countries with laxer regulations or operations are transformed to circumvent these regulations. In defense of those who did this, it must be said that this was legal, at least in many cases. However, this does not mean that they were not irresponsible or ethically dubious: not everything that is legal is ethical.

The lack of transparency is another feature of many of the conducts that led to the crisis. It is reasonable to expect that a hedge fund will not reveal its strategies, as they are the secret of its success, a secret that cannot be protected by patents. However, the lack of clarity in the operations, the concealment or misrepresentation of the information given to clients (and, often, also to regulators and even to stockholders) makes one think that the managers of some funds knew that they were carrying out immoral operations of doubtful legality. And the lack

\footnotetext{
${ }^{21}$ In addition to other problems, such as the inadequacy of their models, the lack of a long and varied track record to factor into the models' parameters, and the fact that their best analysts ended up being hired by their clients (which exacerbated the conflict of interests).

22 "You [the manager of a financial institution] earn a stream of steady bonuses for seven or eight years, then when the losses take place, you are not asked to disburse anything (...) As you do not disgorge previous compensation, the incentive is to engage in trades that explode rarely, after a period of steady gains" (Taleb, 2009).

${ }^{23}$ The Madoff case also reveals other social and ethical problems affecting investors: pride (the desire to feel part of a privileged elite of investors), imprudence (trust in an analyst's expertise without verifying that he actually has the expertise) and a certain degree of obfuscation (the "desire" to believe that it is possible to earn returns in excess of $10 \%$ indefinitely).
} 
of transparency can also cover up blatant lies. ${ }^{24}$ These companies' managers and analysts "valued honor, glory, riches, fame and the like, which they could only attain through professional excellence or by cheating, and proved willing to cheat rather than restrain their desires or reorient their values" (Torres, 2009, p. 10).

The list of virtues violated in the recent crisis also includes temperance and self-control, that is, the ability to restrain the desire for success, wealth or social recognition, when this becomes an obstacle to proper performance of one's professional duties. And also cowardice and weakness: some managers probably realized what was happening and suspected that what they were doing was not right, or that what was happening around them was leading to a crisis that could cause significant damage to the company, its clients and society as a whole, but they were incapable of making the difficult decisions they should have made, for fear of endangering their career or their bonuses, or making waves, or because they thought that it was not their duty or responsibility. Or perhaps they thought that if the crisis did happen, somebody else would come along and shoulder the financial burden of rescuing the endangered institutions.

No doubt there were also people who showed pride, high-handedness, and arrogance in their behavior, starting with certain financiers who were then followed by economists, regulators and authorities; people who were convinced that their knowledge was superior to that of others, that they did not have to submit to other people's decisions or supervision, or that they were above the law and moral norms.

All of this inevitably led to situations of injustice. Many of these situations come under the sphere of commutative justice (Pieper, 1966), when they affect what is owed to other people, including problems of concealing information, ${ }^{25}$ misleading advertising, deal churning to generate higher commissions, inaccurate recommendations on securities, etc. And other situations pertain to distributive justice, which refers to the distribution of costs and benefits in society. These include, for example, the moral problems generated by moral risk: financial institutions took advantage of their limited liability status or the existence of guarantees that limited their losses to take on higher risk levels than they would accept if they had to cover themselves all their potential losses (Sinn, 2008). ${ }^{26}$

\section{Imprudence}

Prudence is the chief virtue of the banker (Termes, 1995) and of the businessman in general. However, it is difficult to exercise this virtue, particularly in the conditions that have prevailed in recent years. Some of these conditions are related to the general economy: high growth, abundant liquidity, low interest rates, moderate and stable inflation... The effects have been to increase the leverage of families and financial institutions and reduce the perception of risk, creating a favorable environment for poor risk management (personal, shared and systemic

\footnotetext{
${ }^{24}$ Lewis (2008, p. 4) quotes one banker as saying: "I did subprime first. I lived with the worst first. These guys lied to infinity".

${ }^{25}$ Many structured assets are genuine "lemons", because of asymmetric information problems (Akerlof, 1970).

${ }^{26}$ This is related in turn to other problems, such as management compensation, particularly the generous golden handshakes they took with them when they left, irrespective of the damage they caused to the organization during their term. Or with the possibility of creating off-balance sheet organizations to which highly leveraged assets were transferred, which again implied excessively high risk levels.
} 
risk) by financial institutions, families, companies (real estate companies, for example) and regulators.

These imprudent conducts take many forms. Complacency, for example, is common in the boom stage before the crisis and manifests as an underestimation of the risk of loss due to the abundance of funds, low interest rates, the opportunities for high earnings, the coverage (often only apparent) provided by financial derivatives and the confidence derived from seeing that many other agents are following the same behavior (Lo, 2008) $)^{27}$. And the flip side of the confidence coin in the crisis stage is panic (for example, in October 2008).

Related to complacency and panic is herd behavior: for example, buying when everyone else is buying and selling when everyone else is selling. This can be a rational conduct that minimizes losses when markets are falling but it also has the effect of exacerbating the fall, spreading it to other markets, and may lead to scares, which are also herd behaviors. This also raises ethical problems for decision-makers: what is the best decision from the economic and moral viewpoint when there is no time to think? Is it possible to leave the herd when everyone is making decisions that may, at the very least, be imprudent? ${ }^{28}$

Another example is given by the cases of poor governance and professional incompetence on the part of chairmen, directors, CEOs, managers, analysts, etc. For example, the job of analyzing and valuing structured financial assets, and even decisions to buy and sell, were often entrusted to young people with insufficient financial knowledge, who did not know what they were dealing with, who lacked experience (particularly in situations of crisis) and who used sophisticated models based on a series of assumptions that were excessively simplistic but which no-one dared to question because nobody had any that were better. ${ }^{29}$ To make matters worse, these experts' superiors, who were the people who could and should correct their decisions, did not know what they were doing and did not understand the models they were using - and so the process continued right up to senior management and the board of directors. In other words, what was lacking was "an understanding of the mechanics of structured products combined with the economic knowledge to put them in context and the management skills to run the organizations that marketed them" (Kay, 2009a). ${ }^{30}$

"As long as the music is playing, you've got to get up and dance", Charles 0. (“Chuck") Prince, CEO of Citigroup, said to the Financial Times in July 2007. And he added: "We're still dancing". This sentence sums up very aptly what business has been for many financiers in recent years: a

\footnotetext{
${ }^{27}$ A typical case is to consider that unlikely events are impossible in practice (Taleb, 2007).

${ }^{28}$ One particular form of herd behavior is the obsession with short-term goals which, as we have said, creates perverse incentives: abandonment of long-term strategies (long-term investments, for example, or spending on research, which the markets usually penalize because the earnings they bring are only realized much later), managing the company with a view to short-term stock market movements ("play looking at the scoreboard, not the ball”), possible fraudulent actions to maximize return, etc. They suffer from the problem we have already mentioned: is it possible to abandon a strategy driven by the short term when it is the only strategy that competitors and analysts know how to follow? Can a company remain aloof from the standards, conventions, regulations or ideas that currently prevail in an industry? Cf. Jacobides (2009).

29 The issue of the economists' and finance theorists' responsibility merits a searching study in its own right (Acemoglu, 2009).

${ }^{30}$ And this author adds: "It is doubtful whether anyone at all had this range of abilities".
} 
frenzied dance which, just like in the musical chairs game, nobody could leave. "Those words now serve as the epitaph for the global credit and mortgages boom" (Mackenzie, 2009). ${ }^{31}$

\section{Who takes care of the common good?}

If, as we have pointed out, the crisis is due to a large extent to regulatory and supervisory failures, this raises another important question: who takes care of the common good in the financial system ${ }^{32}$ Or, at least, who is responsible for the consequences that individual decisions have for other people? Because, as the financial crisis has shown, it is not sufficient to foresee and cover personal risks: asset fire sales by a financial institution causes the price of those assets held by other organizations to fall, spreading the effects of the crisis, which may then become systemic and affect the stability of all institutions. Who should be responsible for counteracting these effects?

The first candidate is the market itself. But the crisis has made it plain that, unaided, the market is incapable of doing this when there are "market failures," such as the existence of public goods (confidence is a public good and its loss has harmful effects for everyone), externalities (such as falling prices of an asset caused by sell-offs in another market), the existence of incomplete markets or behavioral biases (such as overoptimism) (Lo, 2008).

So it becomes necessary to fall back on the State - law and regulation -, the traditional candidate for this role, particularly in considering all the relevant variables in the short and long term; that is, evaluating a broad range of possible effects caused by the agents' actions and current regulations. ${ }^{33}$ But as we have also seen in recent years, there have been a series of failures by the regulators and supervisors, for the reasons we have already mentioned. ${ }^{34}$

Do companies also share any responsibility for their actions' effects on other people and organizations? Yes, if we accept that moral responsibility includes accepting the consequences of past actions and avoiding or correcting the effects that these actions can reasonably be expected to have in the future. And the fact that there are regulators and supervisors does not fully relieve them from this duty, even though the problems are complex and individual institutions can only glimpse some of the consequences.

\footnotetext{
${ }^{31}$ On October 31, 2007, an analyst at Oppenheimer Securities "predicted that Citigroup had so mismanaged its affairs that it would need to slash its dividend or go bust. (...) Four days later, Citigroup's CE0, Chuck Prince, resigned” (Lewis, 2008, pp. 2-3).

32 The social doctrine of the Catholic Church defines the common good as "the sum total of social conditions which allow people, either as groups or as individuals, to reach their fulfillment more fully and more easily" (Pontifical Council for Justice and Peace 2004, n. 164).

${ }^{33}$ In a financial crisis, particular attention must be paid to the systemic risk, i.e., the risk of a system failure against which none of the parties involved can protect itself alone. Note that while this is a function that includes all the regulators, it goes beyond their sphere of responsibility as it implies considering the effects that one agency's actions has on the other agencies. And this is the responsibility of those who hold political power at the very highest level a level that is insufficiently provided for on a world scale, because this global authority does not exist or, when it does exist, it does not have the necessary power, or because its power is not independent from the power of its members.

${ }^{34}$ Also because it is a narrow conception of common good, limited to economic results (growth, efficiency), shortterm effects, or the interests of a particular party or of the majority.
} 


\section{What does the Ethical Interpretation add to the Other Interpretations of the Crisis?}

What would an economist think if an ethical explanation for the crisis, such as that given in the preceding pages, should fall into his hands? He would probably think it reasonable: everything that is said has happened, although he might not call what has happened immoral. But he might also think that an ethical explanation is irrelevant: the crisis, he will say, is an economic phenomenon, its causes (accumulation of risks, excessive leverage, perverse incentives, market failures, regulatory failures) are economic, and its remedies are also economic: we do not need the counsel of ethics which, although probably full of good intentions, will be technically insufficient. And this is true, but only in part.

There are no ethical events: there are events that have economic, political, sociological... and ethical dimensions. ${ }^{35}$ What ethics adds to the economist's explanations is that it identifies another dimension and says that it is important, at least according to the vision of ethics presented earlier. Let us briefly see why (Argandoña, 2008b, d, e).

Decisions have different effects. When the manager of a bank branch sells a financial product to a client, she obtains the financial gain that will enable her to earn her salary - and this is probably the main reason for her action. But there will also be other effects: perhaps she will learn something more about that financial product or about her clients' psychology and she will feel satisfied or dissatisfied with what she has done... Perhaps she did not consciously look for these effects but they will happen. And then there are the effects on the client: he will feel he has been treated well or badly, and his trust in the institution will increase or decrease -now or perhaps in a few years' time if, for example, the product he bought proves to be "toxic".

And the effects on the client will also have consequences for the bank manager: not because she may lose her salary if the client feels cheated but because of the learning that her behavior will produce. And this is where we enter the realm of ethics. If she lied to sell the financial product, she has endangered her credibility and that of her bank, and she has learned how to lie: she has become a liar. And if she has forced her subordinates to lie too, she is reducing the level of trust within the bank and she has become an unjust person. And if she is prepared to put her bonus before her client's legitimate interest, she has become unjust again and she has developed her ability to continue being unjust. And if she has lobbied to change a regulation that controlled her bank's risk, she is creating the conditions that will enable other banks to also take on too much risk, which may lead to a systemic risk with damaging effects for society as a whole.

The economic interpretations of the crisis are correct but they omit these consequences on the decision-makers themselves (they learn to do good or evil) and on other people (they create moral or immoral cultures, they foster or destroy trust, they spread the consequences of one's actions to other organizations). What ethics adds to economics is a richer conception of human motivations. As a result, the explanations may not be different but they are definitely more complete and they enable better definitions to be given of the consequences - particularly the long-term consequences - of economic decisions. And this serves to 1) identify problems before they are seen by the economist (if an institution's employees lie in order to sell its products, something has gone awry and, if it is not an isolated incident, sooner or later its consequences

\footnotetext{
${ }^{35}$ The psychological and sociological dimensions also contribute to an explanation of the crisis. Cf., for example, Slovic (2000).
} 
will manifest); 2) gain a better understanding of the nature of the failures that have occurred (the consequences of excessive risk-taking or regulatory arbitration are not just economic), and 3) design better solutions. And these solutions will be given by the economist, not by the moralist, who does not know how to design a regulation or articulate a proper valuation of a portfolio's risk. But the economist would do well to take ethical criteria into account if she wants to avoid her recommendations from having the negative effects we have identified in the present crisis.

\section{Could Corporate Social Responsibility have Averted the Crisis?}

When looked at from the viewpoint of the financial organizations and the bodies that regulate, supervise and control them, this crisis has been, above all, a management crisis. After explaining how Meredith Whitney discovered the deplorable state of affairs at Citigroup in October 2007, Lewis (2008, p. 3) concludes: "this woman was not saying that Wall Street bankers were corrupt. She was saying they were stupid”. They achieved fabulous profits for years, high prices for their banks' stock, prestige, personal power, reputation and succulent salaries, but they were not good at managing their companies. And we say this not just because of the effect their dismal performance had on their companies but because they did not behave as responsible, ethical managers. Because ethics is not an add-on to a (good or bad) technical management, like the icing on the cake: it is part of the cake itself.

And this leads us to the questions with which we opened this paper: Could CSR have averted the crisis, can it remedy it now and can it prevent further financial crises from happening in the future?

\section{Corporate Social Responsibility and the Crisis of the Financial Institutions}

CSR is concerned with the management of organizations, not of economic systems. ${ }^{36}$ Our thesis is that a company that acts in accordance with CSR, as we have explained above, will be a well-managed company. But this does not mean that it will not make mistakes (for example, about the likely growth of a market or the possibilities of a new technology), or that it will not suffer the consequences of changes in its environment (such as the depreciation of a currency, a fall in aggregate demand or a wave of terrorist attacks or social conflict). In other words, it is likely that a responsible company will survive and prosper but it is also possible that it will not.

If we cannot guarantee the success of a responsible company, then nor can we guarantee that of a country: even if all of its companies behave responsibly, it is not certain that it will achieve a high rate of sustainable growth or a low unemployment rate or greater macroeconomic stability. As we have already said, a financial crisis is not only averted through correct behavior by all of the agents but also by the quality and efficiency of its regulatory, supervisory and control mechanisms. We have already remarked that serious mistakes have been made in this crisis (in risk management, forecasting, perverse incentives, etc.) which

\footnotetext{
${ }^{36}$ And if there is a "social responsibility of the economic system", I do not think that it has been studied yet.
} 
affected the regulatory and supervisory mechanisms and whose ultimate consequence has been a severe systemic failure. ${ }^{37}$

And it will be even more difficult to avert a financial crisis in an environment in which a not insignificant number of financial institutions are not behaving responsibly: because the creation of perverse incentives, the manipulation of regulations and the spillover effects from certain institutions and markets onto others will have a greater destabilizing effect - and this probably happened in the 2007 crisis.

So what use is CSR if it is unable to prevent a system crisis? I would suggest three important tasks.

First, it could have prevented certain institutions from going bankrupt, or at least it would have made it less likely. We have already said that many irresponsible acts were performed, from the excessive leverage of off-balance sheet operations and the resulting excessive risk-taking, to the conflicts of interest that were tolerated and even encouraged within organizations; from the compensation schemes that rewarded short-term earnings, at the very best, or led to these earnings being captured by the managers and not by the stockholders, to regulatory arbitration operations to lessen the controls, to the point of lying and cheating, on many occasions. It seems that many of these managers did not act in accordance with a fiduciary duty, not just towards the various stakeholders but also not even towards their companies' own stockholders. In short, as we have already said, these behaviors show a lack of professionalism, prudence and other virtues that were necessary for proper management of these organizations.

Second, it might have contributed to creating a different climate in the business world. If, as we suggest above, every individual has some responsibility for the common good, the managers of these institutions should have taken into account their decisions' consequences not only for their stockholders but also for other people: their employees, whose jobs were endangered by their inadequate management and who were made accomplices to conducts of doubtful morality; their clients, to whom, for example, they sold "toxic" assets without informing them of the risks they were taking when they bought them; other financial institutions, which they forced, in one way or another, to take part in the "dance", blocking the implementation of sensible policies; and the managers themselves, who harmed themselves, their reputation and their future.

\section{Trust}

The third function performed by CSR in preventing a crisis, and also in getting out of one, is the creation and maintenance of trust, whose loss has been one of the most significant consequences of the present crisis. We attribute this loss to technical reasons, such as the lack of transparency in the content of the structured products, but the problem goes deeper than that: people have lost trust in the organizations and in the people who run them or work in them. What has happened?

Originally, trust refers to relationships between people. However, in a world in which contacts multiply and become depersonalized, particularly in the financial markets, we have ended up placing our trust in other things. First of all, in the law or in the rules: we say that the depositor

\footnotetext{
37 This takes us to the issue of the social responsibility of governments, legislators, regulators and controllers, which we will not discuss here.
} 
trusts the bank because he knows that there is a law that requires the bank to diligently safeguard his money and return it to him whenever he asks for it. Second, in the institutions: if the bank cannot return the deposit, the deposit insurance corporation will honor this obligation. And third, in the financial institutions' own interest, that is, in their ability to interiorize their obligations, irrespective of whether or not there is a law that gives them legal force, because it is in their interest and they are bound to do so by the existence of competition. For many years, this seemed to be the deepest reason for our trust in the financial system. To quote Alan Greenspan (2007), ${ }^{38}$ "the first and most effective line of defense against fraud and insolvency is counterparties' surveillance. For example, JPMorgan thoroughly scrutinizes the balance sheet of Merrill Lynch before it lends. It does not look to the Securities and Exchange Commission to verify Merrill's solvency".

However, all this suddenly collapsed. Law by itself cannot create trust: in fact, if the law is effective, trust is not necessary, but if it ceases to be effective, what can one trust in? ${ }^{39}$ Nor can we trust the organizations' capacity for self-control, as they have clearly shown their incapacity for this.

So we are brought back to personal relationships. Trust between two people has two components, both of which are necessary: one is functional (also called technical or skill-based) and the other is personal (or ethical or benevolence-based) (Pérez López, 1993; Rosanas and Velilla, 2003). Functional trust is related to the skills and technical knowledge of the person we trust. In the example we gave earlier, the bank's managers and employees must be technically capable of running their business, so that the depositor's money is kept safe and he can withdraw it whenever he wishes. Personal trust refers to what moves these people to act: whether, when the time comes, they will be prepared to put the depositor's legitimate interest above the interest of the institution or of the decision-maker himself, that is, whether they will honor their commitment to the depositor, even if they have an interest in behaving otherwise.

In short, personal trust is founded on ethical reasons, either based on personal conviction or on the existence of a strong professional culture, such as that shared by physicians (codes of professional ethics, protection of their reputation, etc.) (Kay, 2009a, b). ${ }^{40}$ And it is incompatible with the behavioral assumptions of agency theory: if the agents (the financial institutions' managers) seek to further their personal interest, resorting to guile and deceit when they consider it to be necessary for their purposes, personal trust is impossible (McKean, 1975).

Restoring trust and creating the necessary conditions that will allow development of a trustbased financial system are two powerful reasons for developing a CSR culture in financial institutions. However, as we have already said, not just any conception of CSR can be used. If, for example, CSR is focused on maximizing value for stockholders, the latter can trust (including on a personal basis) the institution's managers but such trust will not extend to the other stakeholders, starting with the bank's lenders.

\footnotetext{
${ }^{38}$ Quoted by Kay (2009b).

${ }^{39}$ Rather, the situation is the opposite: "the formal organization [law or regulation] is often used to minimize the negative consequences that may be produced because of lack of trust” (Rosanas and Velilla, 2003, p. 56).

40 The personal dimension of trust is always important but particularly when a person does not have the means to gain sufficient knowledge of the matter in hand, as is the case with many financial decisions.
} 


\section{Conclusions}

Could CSR have averted the financial crisis? By itself, probably not. Could it have made it less likely? Probably yes. And less traumatic? Probably yes. Can CSR make it easier to come out of the recession? Probably not, because many organizations do not practice it nor do they have the necessary culture to practice it, and a CSR culture cannot be improvised. Could CSR help specific entities not fall prey to the crisis? Yes, albeit not in all cases because, as we have already pointed out, they are not protected from changes in the environment (liquidity restrictions, increased defaulting, panic reactions by investors, etc.). Were those who acted with social responsibility better managers? Yes, from the ethical viewpoint, although this did not guarantee their technical and managerial suitability. Is it easy to behave in this manner? No, it is not, because this is not the vision that predominates among financial institutions, and because acting against the herd behaviors of investors, competitors, analysts, the media and even regulators - and, of course, of the stockholders - may demand a great strength of will (Argandoña, 2001).

However, these conclusions rest on the concept of CSR that we briefly developed in the first part and may not be valid for other ways of viewing CSR. Following from what we explained earlier, CSR implies accepting the responsibilities inherent to the managerial function (or that of the analyst, regulator, etc.) as responsibilities towards internal stakeholders (owners, managers, employees) and external stakeholders (clients, suppliers, the financial system as a whole, society, regulators and supervisors) but, first of all, as responsibilities towards oneself: they are moral responsibilities accepted by the manager as a professional who seeks excellence in everything she does. That is why they become obligations while still being voluntary: not because they are imposed by laws or regulations but because they are accepted by the agent herself as obligations that are intrinsic to her profession and her job.

On a moral plane, these responsibilities entail accepting the consequences of one's decisions, when they have been made freely, even when such consequences are costly - including the possible moral obligation to compensate those who have been harmed by the decision, even when this is not required by law. ${ }^{41}$ They include compliance with the law but also go beyond this. They entail a duty (which may vary depending on the circumstances) to take into account the consequences that one's actions have for others, including the consequences for society as a whole: if a bank's decisions may have significant spillover effects to the extent of becoming systemic risk factors, the decision-maker cannot refrain from considering these effects. The content of the responsibilities towards internal stakeholders will be those characteristic of any human organization, but the content of the external responsibilities will derive from the financial institutions' social function, i.e., they refer directly to the ethical errors and omissions that have led to the crisis.

For all these reasons, we believe that the crisis and its consequences would have been different if a large number of agents had been moved by this ethical responsibility and acted accordingly. Whether or not such a belief is realistic, given the history of finance, is another matter. But at least our conclusions may be useful in foreseeing and averting future crises.

\footnotetext{
${ }^{41}$ This may be very effective in restoring trust.
} 


\section{References}

Abberger, K. and W. Nierhaus (2008), "How to define a recession?," CESifo Forum, 4/2008, pp. 74-76.

Acemoglu, D. (2009), "The crisis of 2008: Structural lessons for and from economics," MIT, January.

Akerlof, G. (1970), “The market for 'lemons': qualitative uncertainty and the market mechanism," Quarterly Journal of Economics, 84, pp. 488-500.

Argandoña, A. (1995a), "The treatment of ethical problems in financial institutions and markets," in A. Argandoña, ed., The Ethical Dimension of Financial Institutions and Markets. Berlin: Springer Verlag, pp. 1-26.

Argandoña, A. (ed.), (1995b), "The Ethical Dimension of Financial Institutions and Markets," Berlin: Springer Verlag.

Argandoña, A. (2001), "Managing and acting 'beyond the call of duty'," Business Ethics: A European Review, 10 (4), pp. 320-330.

Argandoña, A. (2004), "Conflicts of interest: the ethical viewpoint," Working Paper, IESE, No. 552, May.

Argandoña, A. (2008a), "The ethical dimension of corporate social responsibility," presented at the 2008 EBEN-UK Annual Conference, Cambridge, 1-2 April.

Argandoña, A. (2008b), "Anthropological and ethical foundations of organization theory," in S. Gregg and J. R. Stoner (eds.), Rethinking Business Management. Examining the Foundations of Business Education, Princeton, NJ: The Witherspoon Institute, pp. 38-49.

Argandoña, A. (2008c), "Ethical foundations of corporate social responsibility," in E. Bettini and F. Moscarini, (eds.), Responsabilità Sociale d'Impresa e Nuovo Humanesimo. Genova: Sangiorgio Editrice, pp. 31-56.

Argandoña, A. (2008d), "Integrating ethics into action theory and organizational theory," Journal of Business Ethics, 78 (3), pp. 435-446.

Argandoña, A. (2008e), “Consistency in decision making in companies," presented at the Seminar "Humanizing the company and the management profession", IESE, June 30 - July 2.

Argandoña, A. (2008f), “La ética en los negocios," in CAI en el Siglo XXI. La Ética, Zaragoza: Caja de Ahorros de la Inmaculada, pp. 66-77.

Argandoña, A. (2009a), "The common good of the company and the theory of organization," Working Paper WP 777, IESE Business School, January.

Argandoña, A. (2009b), "Financial crisis: a la búsqueda de unos criterios éticos," presented at the Seminar "La situació econòmica global. A la recerca d'uns criteris ètics", Barcelona, February 10. 
Argandoña, A., A. Lariu, and R. Morel (2009b), "La responsabilidad social de las instituciones microfinancieras: contribuyendo a la reducción de la pobreza," Cuadernos de la Cátedra "la Caixa" de Responsabilidad Social de la Empresa y Gobierno Corporativo, IESE Business School, No. 3, March.

Baily, M. N., R. E. Litan, and M. S. Johnson (2008), "The origins of the financial crisis," Fixing Finance Series Paper 3, Washington DC., Brookings Institution.

Beckmann, M. and I. Pies (2007), "Responsibility and economics”, Diskussionpapier Nr. 2007-6, Lehrstuhls für Wirtschaftsehitk an der Martin-Luther-Universität Halle-Witenberg.

Boatright, J. R. (1999), “Ethics in Finance,” Malden, MA: Blackwell.

Bogle, J. (2006), "The depth and breadth of the financial scandals," Challenge, 49 (2), MarchApril, pp. 23-32.

Bordo, M. D. (2008), “A historical perspective of the crisis of 2007-2008," NBER Working Paper No. 14659, Cambridge, MA: National Bureau of Economic Research.

Brunnermeier, M. K. (2008), “Deciphering the liquidity and credit crunch 2007-08," NBER Working Paper No. 14612, Cambridge, MA: National Bureau of Economic Research.

Carrasco, I. (2006), "Ethics and banking," International Advances in Economic Research, 12, pp. 43-50.

Carroll, A. B. (1979), "A three-dimensional conceptual model of corporate performance," Academy of Management Review, 4 (4), pp. 497-505.

Claessens, S., M. Ayhan Kose, and M. E. Terrones (2008), "What happens during recessions, crunches and busts?," IMF Working Paper No. WP/08/274, Washington, DC: International Monetary Fund.

Cowton, C. J. (2002), "Integrity, responsibility and affinity: Three aspects of ethics in banking," Business Ethics: A European Review, 11, pp. 393-400.

Cowton, C. J. and P. Thompson (1999), "Ethical Banking: Progress and Prospects," London: Financial Times Business.

Crotty, J. and G. Epstein (2008), "Proposals for effectively regulating the U.S. financial system to avoid yet another meltdown," Working Paper 2008-15, Department of Economics, University of Massachusetts, Amherst, MA: University of Massachusetts.

de Villiers, E. (2002), “Who will bear moral responsibility?,” Communication, 28 (1), pp. 16-21.

Diamond, D. W. and R. Rajan (2009), "The credit crisis: Conjectures about causes and remedies," NBER Working Paper No. 14739, Cambridge, MA: National Bureau of Economic Research.

Donaldson, T. and L. E. Preston (1995), "The stakeholder theory of the corporation: Concepts, evidence, and implications," Academy of Management Review, 20 (1), pp. 65-91.

Eichengreen, B. (2008), "Origins and responses to the current crisis," CESifo Forum 4/2008, pp. 6-11.

Eshleman, A. (2004), "Moral responsibility," in E. N. Zalta (ed.), Stanford Encyclopedia of Philosophy, www.plato.stanford.edu/entries/moral-responsibility. 
European Commission (2001), “Green Paper. Promoting a European Framework for CSR," COM (2001) 366 final, 18.7.2001.

Fischer, J. M. (1999), “Recent work on moral responsibility,” Ethics, 110, pp. 93-139.

Gössling, T. and R. Jansen (2006), "Corporate social responsibility versus business ethics," Tilburg University.

Greenspan, A. (2007), “The Age of Turbulence: Adventures in a New World," New York, NY: Penguin Press.

Haig, M. and J. Hazelton (2004), "Financial markets, a tool for corporate social responsibility," Journal of Business Ethics, 52, pp. 59-71.

Hart, H. L. A. (1968), "Punishment and responsibility," New York, NY: Oxford University Press.

Hellwig, M. (2008), “The causes of the financial crisis," CESifo Forum, 4/2008, pp. 12-21.

Hogan, W. P. and I. G. Sharpe (1997), "Prudential regulation of the financial system: A functional approach," Agenda, 4 (1), pp. 15-28.

International Chamber of Commerce (2002), “A business vision for the 21st century,” Paris: ICC.

Jacobides, M. G., (2009), "New thinking about how to do business," Financial Times Mastering Management, February 13, pp. 2-3.

Jonas, H. (1984), "The Imperative of Responsibility. In Search of an Ethics for the Technological Age," Chicago, IL: University of Chicago Press.

Kane, E. J. (2008), "Ethical failures in regulating and supervising the pursuit of safety net subsidies," Networks Financial Institute, Indiana State University, Working Paper No. 2008-WP12 , September.

Kane, E. J. (2009), "Incentive roots of the securitisation crisis and its early mismanagement," CEPR Policy Insight No. 32, London: Center for Economic Policy Research, March.

Kay, J. (2009a), "Introduce professional standards for senior bankers," Financial Times, February 18.

Kay, J. (2009b), "Greenspan could have found a cure at the pharmacy," Financial Times, February 25.

Kindleberger, C. P. (1978), "Manias, Panics and Crashes: A History of Financial Crises," New York, NY: John Wiley \& Sons.

Lewis, M. (2008), “The end,” in www.portfolio.com.

Lo, A. W. (2008), “Hedge funds, systemic risk, and the financial crisis of 2007-2008," prepared for the U.S. House of Representatives Committee on Oversight and Government Reform, November 13.

Lynch, J. J. (1991), “Ethical Banking: Surviving in an Age of Default,” Basingstoke: Macmillan.

Lynch, J. J. (1994), “Banking and Finance: Managing the Moral Dimension,” Cambridge: Gresham. 
Mackenzie, M. (2009), "Cautionary tale from Citi for new giants of finance," Financial Times, January 17.

McKean, R. N. (1975), "Economics of trust, altruism, and corporate responsibility," in E.S. Phelps (ed.), Altruism, Morality, and Economic Theory, New York, NY: Russell Sage, pp. 29-44.

Mendoza, E. and M. E. Terrones (2008), "An anatomy of credit booms: Evidence from macro aggregates and micro data," NBER Working Paper No. 14444. Cambridge, MA: National Bureau of Economic Research.

Merton, R. and Z. Bodie (1995), "A conceptual framework for analyzing the financial environment," in D. Crane, K. Froot, F. Mason, A. Perold, R. Merton, Z. Bodie, E. Sirri, and P. Tufano, The global Financial System: A Functional Perspective. Boston, MA: Harvard Business School Press, pp. 3-31.

Oshana, M. (1997), “Ascriptions of responsibility," American Philosophical Quarterly, 34, pp. 71-83.

Pérez López, J. A. (1993), “Fundamentos de la dirección de empresas,” Madrid: Rialp.

Pieper, J. (1966), “The Four Cardinal Virtues: Prudence, Justice, Fortitude, Temperance,” Notre Dame, IN: University of Notre Dame Press.

Pontifical Council for Justice and Peace (2004), "Compendium of the Social Doctrine of the Church,” Vatican City: Libreria Editrice Vaticana.

Prior, F. and A. Argandoña (2009a), "Credit accessibility and corporate social responsibility in financial institutions: the case of microfinance," Business Ethics: A European Review, forthcoming.

Rosanas, J. M. and M. Velilla (2003), "Loyalty and trust as the ethical bases of organizations," Journal of Business Ethics, 44, pp. 49-59.

Scanlon, T. M. (1998), "What We Owe to Each Other," Cambridge, MA: Harvard University Press.

Scholtens, B. (2006), "Finance as a driver of corporate social responsibility," Journal of Business Ethics, 68, pp. 19-33.

Scholtens, B. (2008), "Corporate social responsibility in the international banking industry," Journal of Business Ethics, forthcoming.

Sinn, H. W. (2008), “The end of the wheeling and dealing," CESifo Forum, 4/2008, pp. 3-5.

Slovic, P. (2000), “The Perception of Risk,” London: Earthscan Publications.

Taleb, N. N. (2007), “The Black Swan: The Impact of the Highly Improbable," New York, NY: Random House.

Taleb, N. N. (2009), "How bank bonuses let us all down," Financial Times, February 25.

Taylor, J. B. (2009), "The financial crisis and the policy responses. An empirical analysis of what went wrong," NBER Working Paper No. 14631, Cambridge, MA, National Bureau of Economic Research. 
Termes, R. (1995), "Ethics in financial institutions," in A. Argandoña (ed.), The Ethical Dimension of Financial Institutions and Markets, Berlin: Springer Verlag, pp. 118-135.

Torres, M. (2009), "Getting business off steroids," in J. Friedland (ed.), Doing Well and Good: The Human Face of New Capitalism, Charlotte, NC: Information Age Publishing, forthcoming.

Watson, G. (1996), “Two faces of responsibility,” Philosophical Topics, 24, pp. 227-248.

Williams, G. (2006), "Responsibility," in The Internet Encyclopedia of Philosophy, www.iep.utm.edu/r/responsi.htm.

World Business Council for Sustainable Development (2000), "Making Good Business Sense," Geneva: WBCSD.

Zamagni, S. (2006), "The ethical anchoring of corporate social responsibility and the critique of CSR," prepared for the 6th International Conference on Catholic Social Thought and Management Education "The Good Society, Catholic Social Thought and Corporate Social Responsibility in Dialogue", Rome, October 5-7. 